\title{
OPEN Characterization of a new bifunctional endo-1,4- $\beta$-xylanase/ esterase found in the rumen metagenome
}

\author{
Gabriella Cavazzini Pavarina ${ }^{1,2}$, Eliana Gertrudes de Macedo Lemos ${ }^{1,3}$, \\ Natália Sarmanho Monteiro Lima ${ }^{1,2}$ \& João Martins Pizauro Jr. ${ }^{1 \bowtie}$
}

Metagenomic data mining of the Nellore cattle rumen microbiota identified a new bifunctional enzyme, endo-1,4- $\beta$-xylanase/esterase, which was subsequently overexpressed in $E$. coli BL21 (DE3). This enzyme was stable at $\mathrm{pH}$ intervals of 5 to 6.5 and temperatures between 30 and $45^{\circ} \mathrm{C}$, and under the test conditions, it had a $V_{\max }$ of $30.959 \pm 2.334 \mu \mathrm{mol} / \mathrm{min} / \mathrm{mg}, \mathrm{K}_{\mathrm{m}}$ of $3.6 \pm 0.6 \mathrm{mM}$ and $\mathrm{k}_{\text {cat }}$ of $2.323 \pm 175 \mathrm{~s}^{-1}$. Additionally, the results showed that the enzyme is tolerant to $\mathrm{NaCl}$ and organic solvents and therefore is suitable for industrial environments. Xylanases are widely applicable, and the synergistic activity of endo-1,4- $\beta$-xylanase/esterase in a single molecule will improve the degradation efficiency of heteroxylans via the creation of xylanase binding sites. Therefore, this new molecule has the potential for use in lignocellulosic biomass processing and as an animal feed food additive and could improve xylooligosaccharide production efficiency.

Lignocellulosic biomass is an important and strategically valuable source of renewable energy, and it has received considerable interest from investors due to its abundance as a raw material and potential use as a biofuel and for bioproduct production ${ }^{1}$. This biomass is composed of high levels of cellulose, hemicellulose and lignin bound by complex connections, which gives it native recalcitrance to enzymatic attacks, thus preventing its easy solubilization and utilization ${ }^{2}$.

Xylan is the most abundant hemicellulose in nature and contains mainly $\beta$-D-xylopyranosyl residues linked by $\beta(1 \rightarrow 4)$ glycosidic bonds. Some xylans have L-arabinofuranosyl and 4 - $O$-methylglucuronic residues in their structure that are linked by $\alpha-1,2$ and $\alpha-1,3$ and present ester bonds with cumaric and ferulic acids ${ }^{3}$. Hemicellulose biodegradation, such as that occurring with xylans, involves the synergistic action of several hydrolytic enzymes (acetyl xylan esterase, $\alpha$-D-glucoronidase and $\alpha$-L-arabinofuranosidase), including main xylanolitic enzymes, such as endo-1,4- $\beta$-xylanases (EC 3.2.1.8) and $\beta$-xylosidases (EC 3.2.1.37) ${ }^{4}$. Endo-1,4- $\beta$-xylanases are responsible for random cleavage of the xylan skeleton at $\beta$ glycosidic bonds $(1 \rightarrow 4)^{3}$, and in the CarbohydrateActive Enzymes Database (CAZY, http://www.cazy.org/) $)^{5}$, they are mainly classified as belonging to the glycosyl hydrolases (GHs) group in the GH10 and GH11 families due to their amino acid sequence homology and catalytic domains ${ }^{6}$.

The conversion of lignocellulosic biomass is complex and requires treatments that can be physical, chemical, enzymatic or a combination of types ${ }^{2,7}$. Enzymatic treatments are environmentally safe and thus more interesting, thereby highlighting the need to characterize new enzymes and identify their functional diversity. Xylanases are widely used as hemicellulose-degrading enzymes and in processes such as saccharification, fruit juice processing, paper production ${ }^{4}$, second-generation ethanol production ${ }^{3}$, xylooligosaccharide production ${ }^{8}$ and xylitol acquisition?.

In the era of big data, the use of a metagenomic approach to query available databases can be valuable for mining and discovering new enzymes ${ }^{10}$, thus facilitating the exploration of the genetic diversity of environments, which cannot be achieved by conventional culture methods. The rumen is a highly efficient lignocellulose converting environment ${ }^{11-13}$, and metagenomic analyses of these structures could enable the identification of

\footnotetext{
${ }^{1}$ Technology Department, School of Agricultural and Veterinarian Sciencess, Sao Paulo State University (Unesp), Via de Acesso Prof. Paulo Donato Castellane S/N, km 5, Sao Paulo, Brazil. ${ }^{2}$ Graduate Program in Agricultural and Livestock Microbiology, School of Agricultural and Veterinarian Sciences, Sao Paulo State University (Unesp), Jaboticabal, Sao Paulo, Brazil. ${ }^{3}$ Molecular Biology Laboratory, Bioenergy Research Institute (IPBEN), Jaboticabal, Sao Paulo, Brazil. ${ }^{\circledR}$ email: j.pizauro@unesp.br
} 

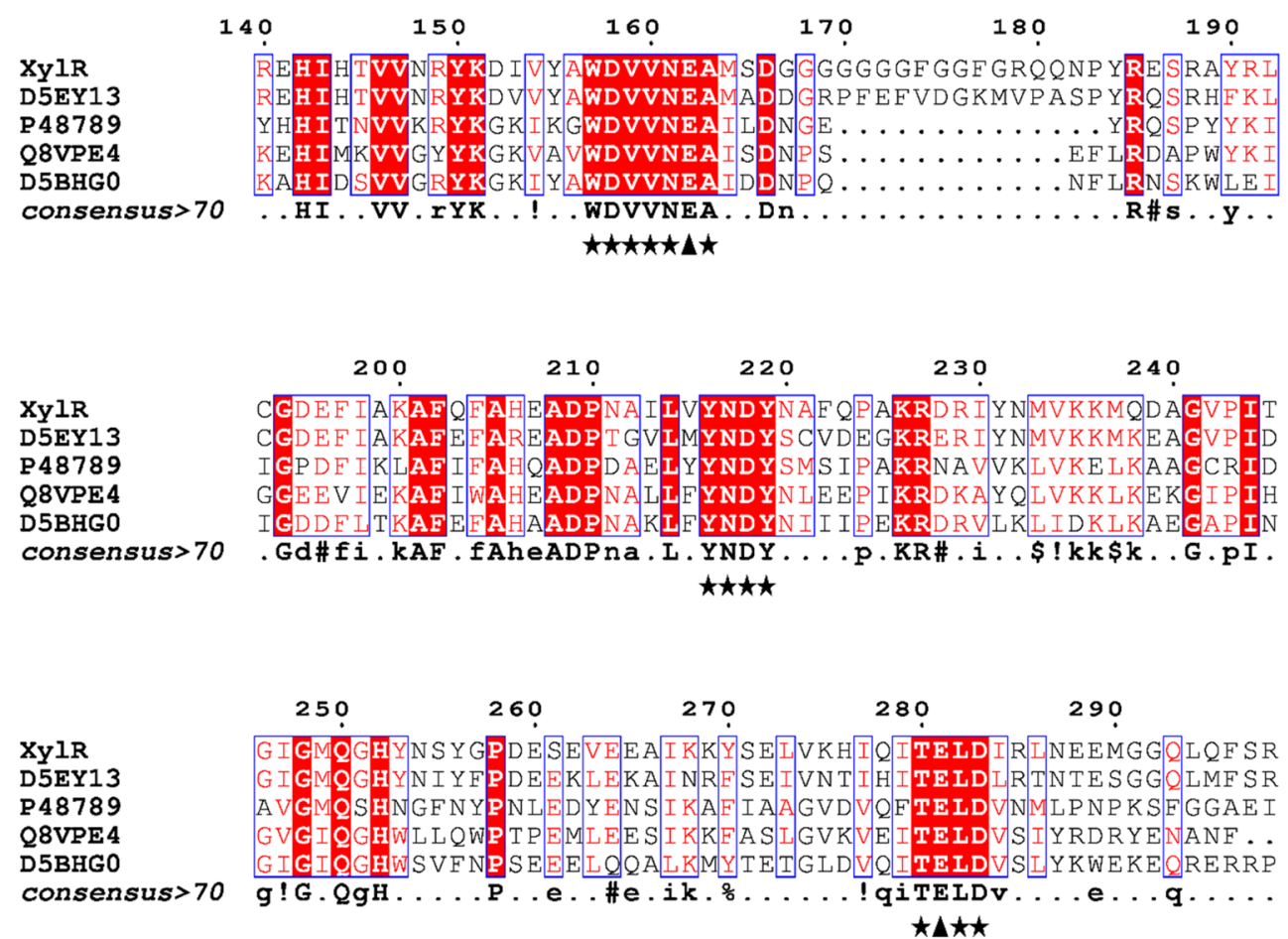

Figure 1. Fragment of the multiple alignment between the amino acid sequence of XylR and xylanases belonging to GH10. The conserved regions are marked with $\star$, and the conserved catalytic residues of glutamate (E) are highlighted with $\mathbf{\Lambda}$. The alignment included xylanase sequences from Prevotella ruminicola (D5EY13), Prevotella ruminicola (P48789), Zunongwangia profunda (ADF53358) and a noncultivable bacterium (AAL06078). Similar amino acids are highlighted in red. Multiple alignment was performed using the Clustal Omega tool ${ }^{16}$, and assembly was performed in EsPript $3.0^{17}$.

new carbohydrases, including xylanases. In this study, we performed metagenomic data mining of the rumen microbiota of Nelore cattle and identified the xylr gene, which is responsible for the production of a bifunctional xylanase esterase that is tolerant to salt and organic solvents. This gene was cloned into an expression vector and purified, and the enzyme was characterized.

\section{Results}

New xylanase gene prospected from the Nelore cattle rumen metagenome. With the aid of a sequence-driven approach to evaluating the metagenomic data of the Nelore cattle rumen (SRX818104), the xylr gene encoding an endo-1,4- $\beta$-xylanase was identified. The $x y l r$ gene contains $2196 \mathrm{bp}$ and 723 amino acids and has a signal peptide of 21 amino acid residues at the $\mathrm{N}$-terminus with a predicted molecular mass of $81.6 \mathrm{kDa}^{14}$. Using the BLASTp tool ${ }^{15}$, endo-1,4- $\beta$-xylanase was shown present $64 \%$ sequence similarity with the endo-1,4$\beta$-xylanase/feruloyl esterase enzyme from Prevotella ruminicola (Table S1) and 66\% similarity to a 2015 United States patent for hemicellulose-degrading enzymes (US 9012186). Multiple sequence alignments and secondary structure predictions demonstrated that the enzyme had the following conserved regions with xylanase GH10: ${ }^{159}$ WDVVNEA $^{163}$ and ${ }^{280}$ TELD $^{283}$ (Fig. 1). Regarding the esterase domain, the presence of the ${ }^{624} \mathrm{GLSMG}^{628}$ motif with a serine (S) was observed at the center of this conserved region (Fig. 2).

XyIR was cloned, expressed in the soluble fraction and purified. The $x y l r$ gene was amplified directly from the rumen metagenomic DNA in the Laboratory of Biochemistry of Microorganisms and Plants (LBMP) database at São Paulo State University, Jaboticabal Campus. Thereafter, it was cloned and expressed in E. coli BL21 (DE3) (Figure S1) using the pET28a(+) vector. A fusion protein with $\mathrm{His}_{6}$ at the C-terminus was obtained. The cloning was confirmed by colony PCR and Sanger sequencing.

The optimum conditions for the expression of the enzyme in E. coli BL21 (DE3) were obtained with a final concentration of IPTG of $0.1 \mathrm{mM}$ and grown at $30^{\circ} \mathrm{C}$ for $22 \mathrm{~h}$ at $180 \mathrm{rpm}$. Under these conditions, the recombinant protein was obtained from the cell lysate supernatant soluble fraction (Fig. 3). The XylR enzyme was purified by immobilized metal ion affinity chromatography (Fig. 3) and later by gel filtration chromatography (Fig. 4). SDS-PAGE analysis showed that the purified enzyme had a molecular weight of $75 \mathrm{kDa}$. The expression and purification of the recombinant enzyme was confirmed by western blot analysis with anti-His6 antibodies, which confirmed that the purified protein was expressed heterologously (Figure S2). 
XYlR

AAM45148.1

4ROT_A

5VOL

6RZO_A

consensus $>70$

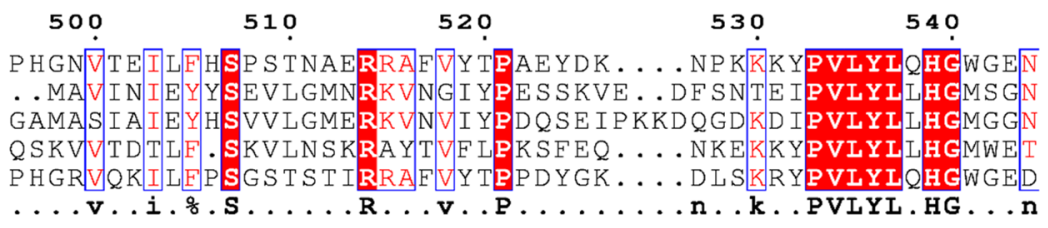

550

560

570

580

590

EYA同SNQGHAGLIMDN L LAEGKAKPEIIVMTYGM. TNDAGEGTLGSFNYKNFE ENSWMIRSGIERIIR .......HTNLAIVMPST ....DIGEYVNTTYG. MNYF ENSWQKRTAIERLLR ....... TTNLIVVMPST ....DIGWYTDTAYG . LNYY NPVWAERGHVIKDVMDRLVASGEACEMIIVT PNAGGN I H IEWNGYF DMP GWKYE ETGWANQGRVNLIMDN L I AEGKARP FI IVMTYGM. TNEIIREGGIREED IRPEQ

AAM45148.1

4ROT_A

5VOL

6RZO A

consensus $>70$

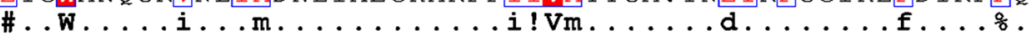

60066106206306
$\mathrm{XY} I \mathrm{R}$

AAM45148.1

4ROT_A

$5 \mathrm{VOL}$

6RZO_A

consensus $>70$
TVLVDEIIPYVD SHERT. IAKRESRAMAGLSMGEMETKNITIARP ETIDWYGL DAIA LELPKVIHNFEPNLSTKKEKNFIAGLSMGGYGAYRLALGT.DHFSYAAS RALS QELPQVILAAF P NMTQKREIKTEVAGLSMGGYGAFKWALKS . NRF SYAAS TFF Y TEF LPYIEKKYRV. I GDR QHRA IAGLSMGGGGATNYGQRHSDMFCAVYA TVLVDELI PYIDANERT. RSDQPHRAMAGLSMGGMETRL I TMNN LDIES S I GL

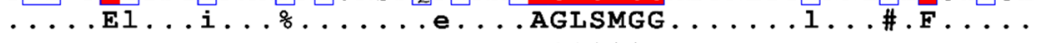

$\star \star \Delta \star \star$

Figure 2. Fragment of the multiple alignment between the XylR amino acid sequence and CE1 family esterases. The conserved regions are marked with $\star$, and the conserved catalytic residue of serine $(S)$ is highlighted with $\boldsymbol{\Delta}$. The alignment includes the esterase sequences of Lactococcus lactis (AAM45148), Bacteroides intestinalis DSM 17,393 (5 VOL), Streptococcus pyogenes (4ROT) and a noncultivable bacterium (6RZO). Similar amino acids are highlighted in red. Multiple alignments were performed using, the Clustal Omega tool ${ }^{16}$ and assembly was performed in EsPript 3.0 ${ }^{17}$.

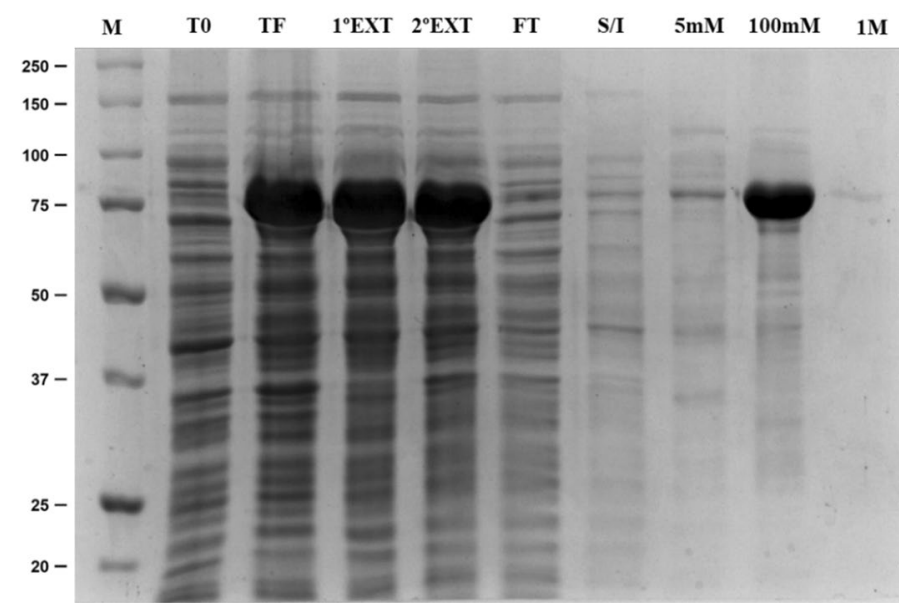

Figure 3. Electrophoretic profile of soluble proteins from E. coli BL21 that were transformed into the vector pET28a/ORF1374. Purification was performed by affinity chromatography on Ni-NTA resin. Channels: (M) Precision Plus marker; (T0) Time before induction; (TF) After $22 \mathrm{~h}$ of induction; ( $1^{\circ} \mathrm{EXT}$ ) First extract; (2nd EXT) Second Extract; (FT) Flow through; (S/I) Fraction without imidazole; (5 mM) Fraction with the concentration of $5 \mathrm{mM}$ imidazole; $(100 \mathrm{mM})$ Fraction with $100 \mathrm{mM}$ imidazole concentration; and (1 M) Fraction with a concentration of $1 \mathrm{M}$.

XylR has a high affinity for xylan and short chain esters. The XylR enzyme has endo-1,4- $\beta$-xylanase (Fig. 5) and esterase activity for short chain esters (Fig. 6). These catalytic properties were determined by the kinetic constants $\left(\mathrm{K}_{\mathrm{m}}, \mathrm{V}_{\max }\right.$, kcat and $\left.\mathrm{kcat} / \mathrm{K}_{\mathrm{m}}\right)$, with xylan from beechwood and p-nitrophenyl acetate used as substrates (Table 1). The comparative hypothesis test between the Michaelis-Menten kinetic model and the sig- 


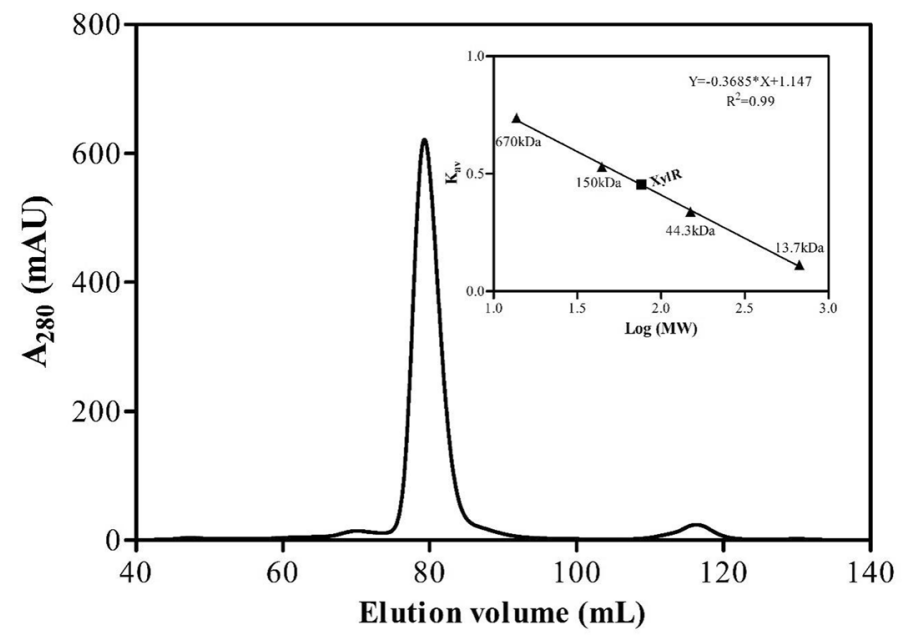

Figure 4. Chromatogram of purified XylR obtained by gel filtration using a Hiload 16/600 Superdex 200 column with a flow rate of $0.7 \mathrm{ml} /$ minute. The internal image corresponds to the linear regression of the chromatography using the Protein Standard Mix $15 \pm 600 \mathrm{kDa}$ standard. Image built by GraphPad Prism software version 5.00. Image built by ImageLab 4.1 software. Notes: Protein Standard Mix $15 \pm 600 \mathrm{kDa}$ : Bovine thyroglobulin $(670 \mathrm{kDa})$; bovine blood $\gamma$-globulin $(150 \mathrm{kDa})$; chicken egg albumin fraction $\mathrm{VI}(44.3 \mathrm{kDa})$ and ribonuclease $\mathrm{A}(13.7 \mathrm{kDa})$.

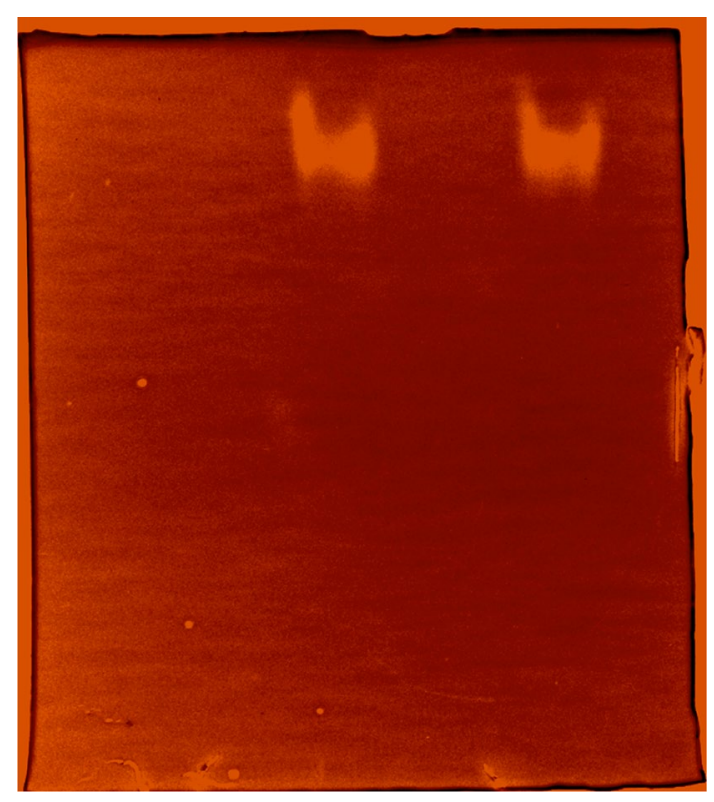

Figure 5. Zimogram for endo-1,4- $\beta$-xylanase activity obtained in a $6 \%$ polyacrylamide gel copolymerized with xylan from beechwood.

moidal kinetic model demonstrated that the enzyme was more adjusted to the Michaelian model in relation to the substrates analyzed (xylan from beechwood $\mathrm{p}=0.1 ; p$-nitrophenyl acetate $\mathrm{p}=0.5$ ).

XyIR activity at neutral $\mathrm{pH}$ and room temperature. Enzyme activity was observed with $0.1 \mathrm{M}$ sodium acetate buffer at $\mathrm{pH} 5.5$ to 6.5, and optimal hydrolysis occurred in this range (Fig. 7). The temperature effect showed that the optimal enzyme activity occurred at $37^{\circ} \mathrm{C}$ and approximately $80 \%$ activity was maintained in intervals of 30 and $45^{\circ} \mathrm{C}$ (Fig. 8). Additionally, the enzyme remained stable when subjected to heat treatments of 45 and $50^{\circ} \mathrm{C}$ for up to one hour (Fig. 9).

XyIR is tolerant to high concentrations of $\mathrm{NaCl}$. The activity of the XylR enzyme decreased by less than $15 \%$ in $\mathrm{NaCl}$ concentrations up to $2 \mathrm{M}$ (Fig. 10). Moreover, enzyme activity was inhibited by $20 \%$ under 


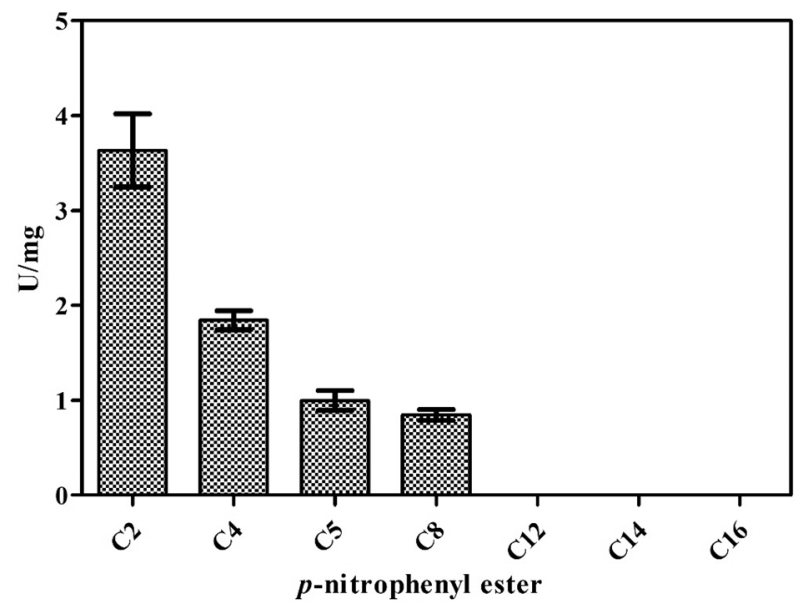

Figure 6. Affinity of XylR for esters of different carbons. Legend: (C2) p-nitrophenyl acetate, (C4) p-nitrophenyl butyrate, (C5) p-nitrofenyl valerate, (C8) p-nitrophenyl octanoate, (C12) p-nitrofenyl dodecanoate, (C14) $p$-nitrofenyl myristate, and (C16) $p$-nitrofenyl palmitate. Values are represented as the mean \pm standard deviation.

\begin{tabular}{|l|l|l|l|l|l|l|}
\hline Substrates & $\mathbf{V}_{\max }(\boldsymbol{\mu m o l} / \mathbf{m i n} / \mathbf{m g})$ & $\mathbf{k c a t}\left(\mathbf{s}^{-1}\right)$ & $\mathbf{K}_{\mathbf{m}}(\mathbf{m M})$ & $\mathbf{k c a t} / \mathbf{K}_{\mathbf{m}}\left(\mathbf{m M}^{-1} \mathbf{s}^{-1}\right)$ & $\mathbf{K}_{\mathbf{m}}(\mathbf{m g} / \mathbf{m l})$ & $\left.\begin{array}{l}\mathbf{k c a t} / \mathbf{K}_{\mathbf{m}}(\mathbf{m g} \\
\mathbf{m l}\end{array} \mathbf{s}^{-1}\right)$ \\
\hline $\begin{array}{l}\text { Xylan from beech- } \\
\text { wood }\end{array}$ & $30.959 \pm 2.334$ & $2.323 \pm 175.1$ & $3.2 \pm 0.6$ & 726.0 & $1.04 \pm 0.18$ & $2.23 \times 10^{3}$ \\
\hline$p$-nitrofenyl acetate & $66.0 \pm 5.2$ & $5,0 \pm 0.4$ & $2.3 \pm 0.4$ & 2.2 & - & - \\
\hline
\end{tabular}

Table 1. Kinetic parameter values calculated for XylR. The values are represented as the mean \pm standard deviation.

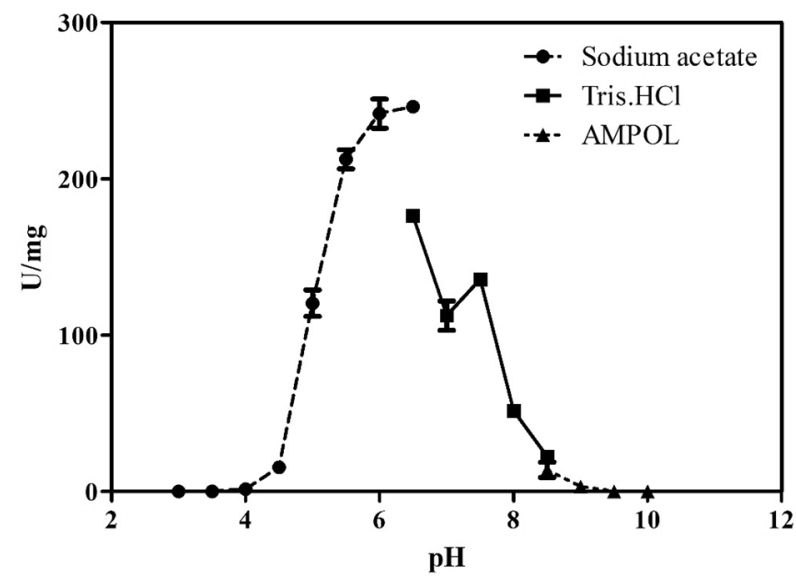

Figure 7. Relative activity at different $\mathrm{pH}$ values and ionic species. Values are represented as the mean \pm standard deviation.

exposure to $2.5 \mathrm{M} \mathrm{NaCl}$ for up to $4 \mathrm{~h}$, and at least $50 \%$ enzymatic activity was maintained with further exposure to this treatment for $8 \mathrm{~h}$ (Fig. 11).

XyIR is tolerant to organic solvents. The effect of different metal ions and EDTA on XylR activity is shown in Table 2. Enzyme activity was reduced by less than $15 \%$ under exposure to $\mathrm{Ca}^{+2}, \mathrm{Mg}^{+2}$ and $\mathrm{Mn}^{+2}$ ions and by $60 \%$ under exposure to $\mathrm{Co}^{+2}$. Moreover, complete inhibition of XylR enzymatic activity was observed with ions $\mathrm{Zn}^{+2}, \mathrm{Hg}^{+2}$ and $\mathrm{Cu}^{+2}$. The presence of EDTA did not inhibit the enzyme, whereas the studied organic solvents (methanol, ethanol, propanol, DMSO, Triton X-114, Triton X-100, Tween 20 and Tween 80) caused inhibitory effects on the enzymatic activity only at concentrations above $20 \%$ (v/v) (Fig. 12). Additionally, XylR 


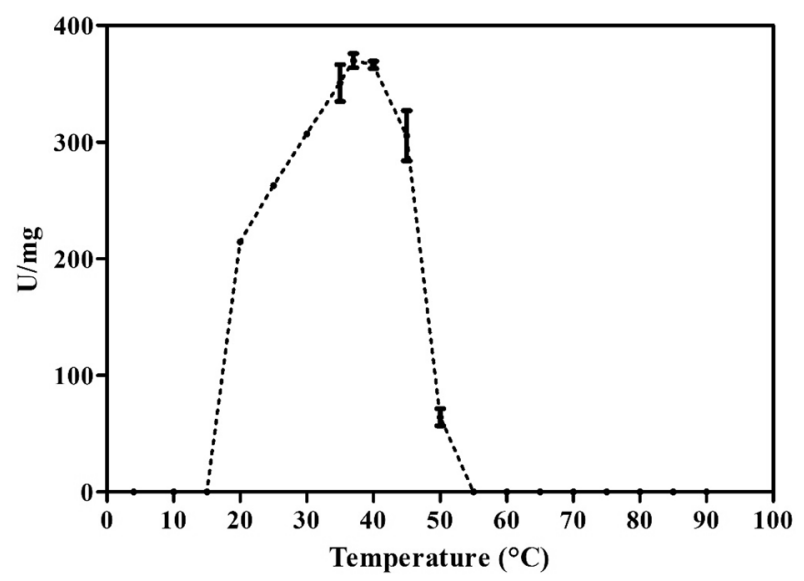

Figure 8. Relative activity at different temperatures. Values are represented as the mean \pm standard deviation.

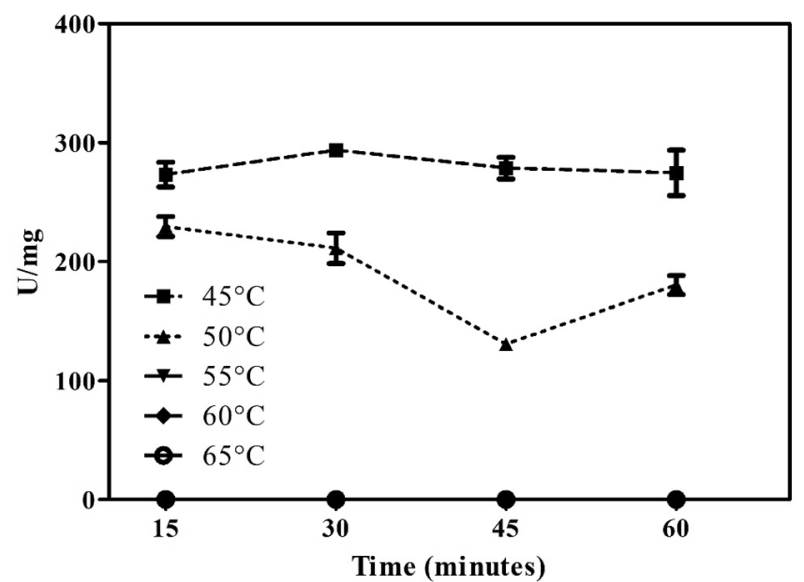

Figure 9. Enzyme stability when submitted to heat treatments of 45 and $50{ }^{\circ} \mathrm{C}$ for up to $60 \mathrm{~min}$. Values are represented as the mean \pm standard deviation.

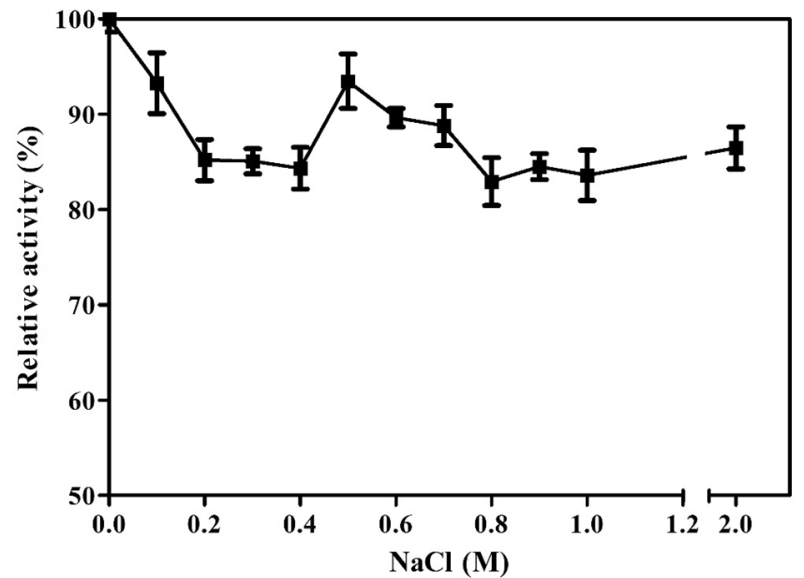

Figure 10. XylR activity in the presence of $\mathrm{NaCl}$ in the reaction medium at concentrations of 0.1 to $2 \mathrm{M}$. Values are represented as the mean percentage \pm standard deviation. 


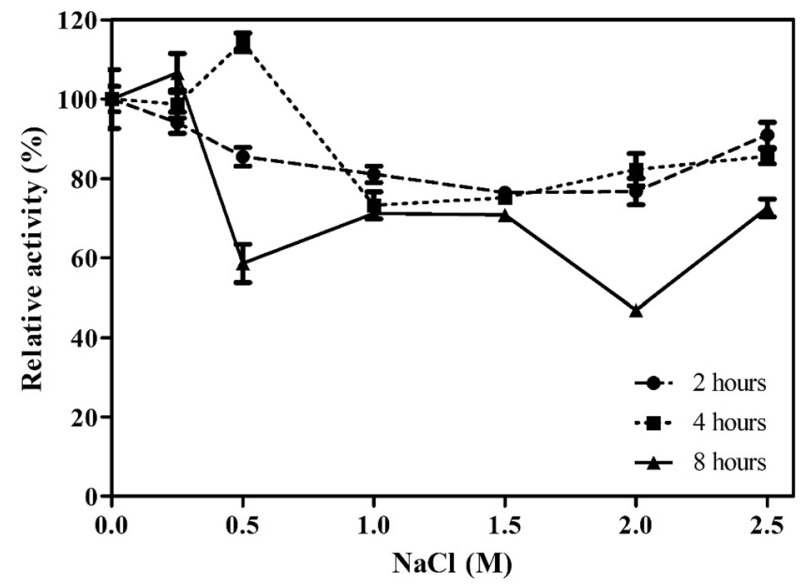

Figure 11. Residual activity after exposure of the enzyme to $\mathrm{NaCl}$ at concentrations of 0.1 to $2.5 \mathrm{M}$ for up to $8 \mathrm{~h}$ at room temperature. Values are represented as the mean percentage \pm standard deviation.

\begin{tabular}{|l|c|l|l|l|l|}
\hline \multirow{2}{*}{ Metallic ions (mM) } & \multicolumn{5}{|l}{ Relative activity (\%) } \\
\cline { 2 - 6 } & $\mathbf{1}$ & $\mathbf{2}$ & $\mathbf{3}$ & $\mathbf{4}$ & $\mathbf{5}$ \\
\hline $\mathrm{MnCl}_{2}$ & $167.8 \pm 3.2$ & $161.5 \pm 2.8$ & $145.7 \pm 11.4$ & $135.8 \pm 4.0$ & $137.6 \pm 3.0$ \\
\hline $\mathrm{MgCl}_{2}$ & $98.0 \pm 2.3$ & $100.7 \pm 2.7$ & $95.0 \pm 0.4$ & $97.8 \pm 1.3$ & $89.2 \pm 2.9$ \\
\hline $\mathrm{MgSO}_{4}$ & $94.1 \pm 3.0$ & $91.0 \pm 3.9$ & $71.0 \pm 16.6$ & $76.7 \pm 8.1$ & $88.7 \pm 1.7$ \\
\hline $\mathrm{CaCl}_{2}$ & $97.5 \pm 0.5$ & $99.9 \pm 0.8$ & $97.1 \pm 2.9$ & $93.9 \pm 1.2$ & $95.4 \pm 2.0$ \\
\hline $\mathrm{CoCl}_{2}$ & $82.4 \pm 1.6$ & $74.7 \pm 2.5$ & $103.0 \pm 0.6$ & $69.0 \pm 0.1$ & $39.5 \pm 1.2$ \\
\hline $\mathrm{ZnSO}_{4}$ & $3.1 \pm 2.0$ & $1.3 \pm 1.1$ & $\mathrm{Nd}$ & nd & nd \\
\hline $\mathrm{ZnCl}_{2}$ & $4.7 \pm 2.1$ & $\mathrm{Nd}$ & $\mathrm{Nd}$ & nd & nd \\
\hline $\mathrm{HgCl}_{2}$ & $3.5 \pm 0.1$ & $4.8 \pm 0.7$ & $4.3 \pm 0.5$ & $\mathrm{nd}$ & $\mathrm{nd}$ \\
\hline $\mathrm{CuSO}_{4}$ & $0.3 \pm 0.1$ & $\mathrm{Nd}$ & $\mathrm{Nd}$ & $\mathrm{nd}$ & $\mathrm{nd}$ \\
\hline $\mathrm{EDTA}$ & $107.2 \pm 2$ & $106.3 \pm 1.5$ & $100.6 \pm 2.6$ & $96.7+3.2$ & $110.2 \pm 3.5$ \\
\hline
\end{tabular}

Table 2. Effect of metallic ions, detergents and organic solvents on XylR activity. Values are presented as the mean percentage \pm standard deviation; nd $=$ not detected.

remained stable in the presence of detergents at the studied concentrations except for Tween 80 at $2 \%$, which resulted in $60 \%$ inhibition of enzymatic activity.

\section{Discussion}

In this study, the XylR enzyme was identified from the rumen metagenome and characterized as a bifunctional xylanase that is tolerant to salt and organic solvents. This enzyme should be a promising candidate for applications in xylan degradation; moreover, its constituent radicals (ferulic acid or p-cumaric acid) are united by ester bonds and can be applied in industrial biotechnological procedures.

The production of recombinant protein from the discovery of new genes has made it possible to leverage the production of lignocellulose-degrading enzymes for the best use of this abundant raw material. Among xylanolitic enzymes, the endo- $\beta$-xylanases of the GH10 and GH11 families are more efficient and have greater temperature and $\mathrm{pH}$ tolerance ${ }^{18}$. The GH10 family can act on low molecular weight cellulose substrates, such as aryl-cellobiosides, and some cell-oligosaccharides ${ }^{4}$ and thus is a better candidate for the degradation of heterogeneous compounds. Because of the ability of GH10 xylanases to act on short, soluble and branched xylo-oligosaccharides, genes that transcribe these enzymes have been identified in metagenomic databases on organisms that are efficient in hydrolyzing lignocellulose, such as ruminants $\mathrm{s}^{11,12,19,20}$ and termites ${ }^{21}$. Such work facilitates the search for these types of enzymes and the identification of their hydrolysis mechanisms and structures.

The gene transcribed by $x y l r$ that was found in the Nelore cattle rumen metagenome shared $64 \%$ similarity with an endo-1,4- $\beta$-xylanase/feruloylesterase from Prevotella ruminicola, which is a gram-negative bacterium and one of the most abundant genera in the bovine rumen ${ }^{22}$. The presence of the two glutamate residues (Fig. 1) in the conserved regions ${ }_{159} \mathrm{WDVVNEA}_{163}$ and ${ }_{280} \mathrm{TELD}_{283}$ reinforces the catalysis mechanism characteristic of the GH10 family based on the retention of the $\beta$ configuration of the anomeric carbon ${ }^{4}$ and signals the presence of this enzyme's active site as well as the conservation of these sequences in different species ${ }^{23,24}$. The presence of serine in the conserved GXSXG region (Fig. 2) signals the active site characteristic of carboxylesterases ${ }^{25}$.

XylR cloning was performed without the signal peptide predicted by SignalP $4.0^{26}$, which optimized the process of obtaining the enzyme from the soluble fraction of E. coli BL21 (DE3), which was purified, and 

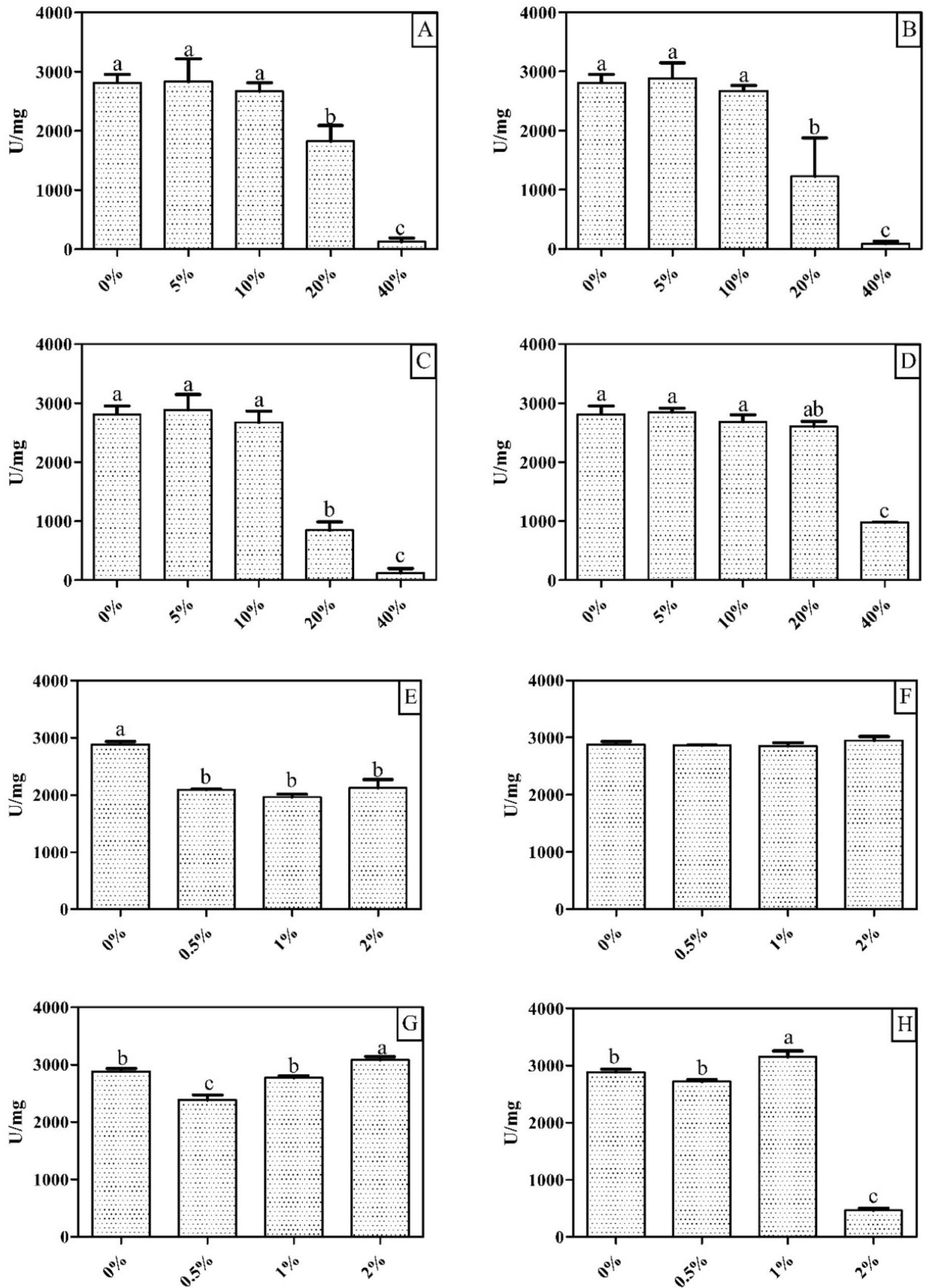

Figure 12. Effect of organic solvents and detergents on XylR activity. (A) Methanol; (B) Ethanol; (C) Propanol; (D) Dimethyl Sulfoxide (DMSO); (E) Triton X-114; (F) Triton X-100; (G) Tween20; (H) Tween80. The lowercase letters $(a, b, c \ldots$ i) indicate significant differences between each condition tested in the experiment according to the ANOVA and Tukey's test at $5 \%$ probability. Values are presented as the mean \pm standard error. 
heterologous enzyme expression was confirmed by western blot analysis. XylR had endo- $\beta$-1,4-xylanase and esterase activities in short chain esters (Fig. 6), which confirms the theoretical predictions of the conserved domains and their bifunctional activity. The kinetic constant values for xylan from beechwood substrate (Table 1) indicate a high efficiency in xylan degradation when compared with those isolated and characterized from species such as Thermotoga thermarum $\left(289 \mathrm{mg} \mathrm{ml}^{-1} \mathrm{~s}^{-1}\right)^{27}$, Remersonia thermophila CBS $540.69\left(417.4 \mathrm{mg} \mathrm{ml}^{-1} \mathrm{~s}^{-1}\right)^{28}$ and Bacillus sp. SN5 (142.6 mg ml $\left.\mathrm{m} \mathrm{s}^{-1}\right)^{29}$. The affinity for $\mathrm{p}$-nitrofenyl acetate indicates that XylR has sterasic activity and is capable of hydrolyzing small molecules containing ester bonds ${ }^{30}$, although its efficiency was similar to that of previously characterized esterases, such as from the fungus Rhizomucor miehei $\left(0.37 \mathrm{mM}^{-1} \mathrm{~s}^{-1}\right)^{31}$ and the bacterium Bacillus pseudofirmus OF4 $\left(3.4 \mu \mathrm{M}^{-1} \mathrm{~s}^{-1}\right)^{32}$. The specificity for short-chain esterase substrates relative to that of endo- $\beta-1,4$-xylanase indicates that this enzyme has an esterase action in addition to that of xylanase, which helps in the digestibility of heteroxylans.

Enzymes with xylanase/esterase bifunctional activity have been previously described ${ }^{33,34}$, and the importance of the synergism between esterase and xylanase activities in hemicellulose degradation has been characterized ${ }^{35}$. The xylan main chain has a high number of ferulic and cumaric acid ester radicals, and the addition of esterases increases their digestibility during bioconversion ${ }^{13}$. The synergistic action of xylanases and esterases is due to the creation of new xylanase binding sites after the cooperative removal of ester radicals between enzymes ${ }^{36}$. In this sense, the enzymatic hydrolysis of ester bonds becomes an important step towards the complete degradation of this type of hemicellulose, which helps to fully utilize lignocellulosic biomass.

The optimal hydrolysis $\mathrm{pH}$ of XylR endo- $\beta$-1,4-xylanase occurred in $0.1 \mathrm{M}$ sodium acetate buffer at $\mathrm{pH} 6.5$ (Fig. 7), and 50\% of its activity was maintained between $\mathrm{pH} 5.5$ and 6.5. This result was similar to that found for endo- $\beta$-1,4-xylanases with different origins and biochemical properties, including a thermostable enzyme of Marasmius sp. (0.1 M sodium acetate buffer, $\mathrm{pH} 6.0)^{37}$; a GH10 family enzyme from Bacillus subtilis B10 (0.1 M citrate-phosphate buffer, $\mathrm{pH} 6.0)^{38}$ and Kitasatospora sp. (0.05 M sodium acetate buffer, $\left.\mathrm{pH} 6.0\right)^{39}$; a salt-resistant strain from Bacillus subtilis cho40 (0.05 M citrate buffer, $\mathrm{pH} 6.0)^{40}$; and an enzyme obtained from the chicken cecum metagenome $(0.05 \mathrm{M} \text { sodium phosphate buffer, } \mathrm{pH} 6.5)^{41}$. This characteristic reinforces that endo- $\beta-1,4-$ xylanases activity occurs at acidic to neutral $\mathrm{pH}$ values, thus indicating the importance of this range of action in different environments.

The endo- $\beta$-1,4-xylanase from XylR exhibited a capacity for hydrolysis at 30 and $45^{\circ} \mathrm{C}$, with optimum hydrolysis occurring at $37^{\circ} \mathrm{C}$ (Fig. 8) and stable hydrolysis occurring at $50^{\circ} \mathrm{C}$ for one hour (Fig. 10). Hydrolysis activity at room temperature is an important characteristic for the solubilization of hemicelluloses, which would not need thermal control in the range of 30 to $45^{\circ} \mathrm{C}$. This result is similar to that for xylanases obtained from other microorganisms, such as Paenibacillus xylanilyticus KJ-03 $\left(40^{\circ} \mathrm{C}\right)^{42}$, Sorangium cellulosum So9733-1 $\left(30^{\circ} \mathrm{C}\right)^{43}$, and Bacillus sp. SN5 $\left(40^{\circ} \mathrm{C}\right)^{29}$.

The $\mathrm{Ca}^{+2}, \mathrm{Mg}^{+2}$ and $\mathrm{Mn}^{+2}$ ions did not inhibit XylR activity, which indicates that this enzyme is tolerant to these metals. $\mathrm{Ca}^{+2}$ and $\mathrm{Mg}^{+2}$ ions are macronutrients normally found in lignocellulosic biomasses ${ }^{44}$, and stable activity of XylR in the presence of these ions reinforces its potential application in hydrolyzing biomasses of different origins. Additionally, the absence of an inhibitory effect of EDTA indicates that XylR is not a metaldependent enzyme, which could be an advantage in large-scale biotechnological processes because this enzyme would not require the addition of metal ions for enzymatic catalysis, thereby reducing the operational cost. However, the metallic ions $\mathrm{Zn}^{+2}, \mathrm{Cu}^{+2}$ and $\mathrm{Hg}^{+2}$ caused total inhibition of XylR activity at low concentrations (Table 2); therefore, these ions should be avoided in biotechnological procedures using this enzyme. The presence of $\mathrm{Cu}^{+2}$-inhibiting xylanases has been described in previous studies ${ }^{39,45}$.

The tolerance of XylR to $2 \mathrm{M} \mathrm{NaCl}$ in the reaction medium (Fig. 10) and $2.5 \mathrm{M}$ for up to $8 \mathrm{~h}$ (Fig. 11) indicates an important characteristic of this enzyme, thus demonstrating its feasibility for use in the biotechnological sector. Halotolerant xylanases have been previously reported ${ }^{40,46,47}$ as feed additives for broilers ${ }^{48}$ and other farm animals because the diets of these animals are routinely formulated with the inclusion of $\mathrm{NaCl}$; moreover, they are included in pretreatments containing high concentrations of $\mathrm{NaCl}$, such as for cellulose solubilization and depolymerization $^{49}$, because they increase the efficiency and synergy between these pretreatments. Additionally, the tolerance of XylR to organic solvents (Fig. 12), such as methanol, ethanol and propanol, at concentrations up to $20 \%(\mathrm{v} / \mathrm{v})$ increases the range of biotechnological processes to which it can be applied, such as the continuous production of lignocellulosic ethanol, in which the saccharification and fermentation steps occur in the same bioreactor ${ }^{50}$. Interactions between the hydrophobic ends of a protein and organic solvents can affect an enzyme's stability; however, XylR showed a low degree of hydrophobicity, which corroborates its resistance to the tested organic solvents.

Xylanases are used in various industrial processes, such as second-generation ethanol production processes ${ }^{3}$, xylooligosaccharide production ${ }^{8}$ and xylitol acquisition ${ }^{9}$. To use lignocellulosic biomass as a raw material, different treatments are required for its solubilization. Currently, efficient treatments to facilitate the use of this material are generally based on chemical compounds that cause environmental contamination ${ }^{2}$; thus, xylanases has been used for the depolymerization of hemicellulose in biotechnological processes.

\section{Conclusions and future perspectives}

In conclusion, data mining of the rumen metagenome identified XylR as a bifunctional enzyme xylanase/esterase that is tolerant to $\mathrm{NaCl}$ and organic solvents, thus indicating the diversity of biomolecules that can be exploited in these environments to overcome current barriers for the production of lignocellulosic biomass. Here, we demonstrate that XylR is able to more efficiently degrade the xylan skeleton and its radical esters in biomasses with a high hemicellulose content. The tolerance of this enzyme to high concentrations of salt makes indicates its versatility and suitability for pretreatments that usually require high concentrations of salts. The use of XylR 
could extend the composition of enzymatic cocktails for the production of lignocellulosic ethanol and food additives in animal feeds and lead to more efficient production of xylooligosaccharides.

In future research, tests will be performed to assay the efficiency of this enzyme in the hydrolysis of lignocellulosic biomass using agricultural waste (e.g., straw and sugarcane bagasse) as raw material and in pretreatments similar to those used in industry to determine its practical applicability. To further understand its structure, $\mathrm{X}$-ray crystallography analysis should be performed to determine its bifunctional activity and its active sites. Additionally, this analysis would help to provide new insights about the behavior of this enzyme under high concentrations of $\mathrm{NaCl}$.

\section{Material and methods}

Bioinformatics analysis. The functions of the xylanase sequence were inferred based on its similarity to the reference sequences of endo- $\beta$-1,4-xylanase from the GH10 family, which was extracted from the American database of the National Center for Biotechnology Information (NCBI), and the sequence was then submitted to the database eggNOG orthologists ${ }^{51}$. Prospecting was performed using the metagenomic database of the Laboratory of Biochemistry and Plant Microorganisms (LBMP) and the Illumina HiScanSQ sequencing data set from Nelore cattle rumen (public data access: SRX818104). ORFs (open reading frames) were selected with an e-value of -30 , aligned with CLUSTALW ${ }^{52}$ and verified for enzymatic domains in the Pfam database $\mathrm{e}^{53}$. The sequences were screened based on predictions in silico in terms of the conserved domains ${ }^{54}$, presence of signal peptides ${ }^{26}$ and similarity to sequences others available at the $\mathrm{NCBI}^{15}$. The secondary structure prediction was performed based on multiple alignment of the sequences by the Clustal Omega tool ${ }^{16}$ (https://www.ebi.ac.uk/Tools/msa/ clustalo/), and assembly and prediction was performed using EsPript 3.0 ${ }^{17}$.

Construction of the recombinant vector. The plasmids were prepared by amplifying the gene encoding the metagenomic DNA of the samples extracted for the sequences available in the LBMP ${ }^{55}$. The following specific primers (Sigma-Aldrich) were synthesized using the commercial PCRBIO Ultra Mix $2 \times \mathrm{Kit}^{26}$ : forward 5'-TATAgaattcTTCGGACGCAATCCAGACACCAATCC-3', which contains the restriction site EcoRI, and reverse 3'-TATAaagcttTTACTTGAACAGCAATTGAG-5', which contains the restriction sites EcoRI and HindIII. The fragment corresponding to the gene was purified by the Zymoclean Gel DNA Recovery Kit from ZymoResearch. The vector pET28a (+) (INVITROGEN) and insert were restricted with restriction enzymes (FastDigest EcoRI, Thermo Scientific; and FastDigest HindIII, Thermo Scientific) and dephosphorylated with the enzyme Fast Alkaline Phosphatase ( $1 \mathrm{U} / \mu \mathrm{L}$, Thermo Scientific). The connection between the insert and the vector was performed according to the protocol of Sambrook and Russel ${ }^{56}$ using the T4 DNA ligase enzyme (New England Biolabs) in a 3:1 ratio (insert: vector).

Transformation and confirmation of cloning. Transformation into competent E. coli BL21 (DE3) cells and positive clone selection were performed on a solid LB plate containing $50 \mathrm{mg} / \mathrm{mL}$ kanamycin. For the positive clones, plasmid DNA was extracted by the Wizard Plus SV Kit minipreps DNA purification System (Promega) and the presence of the gene was verified by conventional PCR and Sanger sequencing. The sequencing of the positive clones was performed on an ABI 3130xl platform, and the sequencing reaction protocol followed that described by the manufacturer of the BigDye Terminator v3.1 Cycle Sequencing Kit and used the T7 forward and T7 reverse primers. The procedures were performed by Dr. Camila Cesário Fernandes at Universidade Estadual Paulista-UNESP, Department of Technology, Centralized Multi-User DNA Sequencing Laboratory and Gene Expression Analysis-LMSeq for sequencing (Process FAPESP: 2009/53984-2). The results of the forward and reverse sequences for each gene were analyzed using the BioEdit Sequence Alignment Editor version 7.2.5 $5^{57}$ through ClustalW ${ }^{52}$ alignment between the contigs and the reference gene obtained from the metagenome.

Expression and purification of the heterologous protein. XylR was expressed in LB pH 7.0 medium (for $1 \mathrm{~L}$ : $10.0 \mathrm{~g}$ of tryptone, $5.0 \mathrm{~g}$ of yeast extract and $10.0 \mathrm{~g}$ of $\mathrm{NaCl}$ ) containing $50 \mathrm{mg} / \mathrm{mL}$ kanamycin and induced with $0.1 \mathrm{mM}$ isopropyl $\beta$-D-1-thiogalactopyranoside (IPTG) after reaching an $\mathrm{OD}_{600}$ of $0.4-0.6$ at $30^{\circ} \mathrm{C}$ for $22 \mathrm{~h}$. The enzyme was extracted in $20 \mathrm{mM}$ Tris $\mathrm{HCl}$ buffer $(\mathrm{pH} 7.5)$ containing $100 \mathrm{mM} \mathrm{NaCl}$ and $10 \%$ glycerol and treated with $1 \mathrm{mg} / \mathrm{mL}$ lysozyme in an ice bath for $1 \mathrm{~h}$. The cells were ruptured by ultrasound with a Branson Sonifier 250 sonicator and centrifuged at $10,000 \mathrm{~g}$ at $4{ }^{\circ} \mathrm{C}$ to obtain soluble extract. Purification was performed by affinity chromatography for immobilized metal ions in Ni-NTA resin (Qiagen, Hilden, Germany), eluted in the $100 \mathrm{mM}$ imidazole fraction and subjected to Hiload 16/600 Superdex 200 column gel filtration (GE Healthcare Bio-Sciences, Uppsala, Sweden) using the ÄKTA pure chromatography system (GE Healthcare, USA). Elution was performed at a flow of $0.5 \mathrm{ml} /$ minute in $20 \mathrm{mM}$ Tris $\mathrm{HCl} \mathrm{pH} 7.5$ buffer containing $200 \mathrm{mM}$ $\mathrm{NaCl}$ and $5 \%$ glycerol.

Biochemical characteristics of XyIR. Polyacrylamide gel electrophoresis in the presence of SDS (SDS-PAGE). Protein samples were analyzed by denaturing electrophoresis on SDS-PAGE polyacrylamide gels $^{58}$. The samples were previously incubated at $100{ }^{\circ} \mathrm{C}$ for five minutes in sample buffer $(62 \mathrm{mM}$ Tris $\mathrm{HCl}(\mathrm{pH}$ 6.8) containing $20 \%$ glycerol, $4 \%$ SDS, $5 \% \beta$-mercaptoethanol and $0.02 \%$ bromophenol blue) and applied in a $10 \%$ polyacrylamide gel containing SDS. Protein separation was carried out by applying an electric field (100 V) for $2 \mathrm{~h}$. The gels were stained using the Coomassie Blue method ( $0.2 \%$ Coomassie Brilliant blue, $40 \%$ methanol, and $10 \%$ acetic acid). 
Western blot analysis. The $10 \%$ SDS polyacrylamide gel containing the protein sample was transferred to a polyvinylidene difluoride (PVDF, Thermo Fisher Scientific) membrane with a porosity of $0.45 \mu \mathrm{m}$ using Mini Trans-Blot (Bio-Rad Laboratories, Hercules, CA, USA) in $10 \mathrm{mM} \mathrm{pH} 11.0$ CAPS buffer containing $10 \%$ methanol at $90 \mathrm{~V}$ for $45 \mathrm{~min}$ at $4{ }^{\circ} \mathrm{C}$. Nonspecific sites were blocked with phosphate-buffered saline (PBS), with Tween $20(0.02 \%)$ and 5\% dry fat-free milk (dilution 1: 1000). The membrane was incubated with the anti-polyhistidine monoclonal antibody (H1029, Sigma, Saint Louis, MO) and the secondary peroxidase-conjugated anti-mouse IgG antibody (A9044, Sigma, Saint Louis, MO). Development was carried out in the presence of 3,3'-diaminobenzidine tetrahydrochloride in $15 \mathrm{ml}$ PBS ( $\mathrm{pH} 7.6$ ) containing $12 \mu \mathrm{l}$ of $30 \% \mathrm{H} 2 \mathrm{O} 2$.

Zymogram. Electrophoresis was performed on a polyacrylamide gel (6\%) copolymerized with 1\% xylan from beechwood in the absence of SDS under $100 \mathrm{~V}$ for $2 \mathrm{~h}$. The sample was previously diluted in a 1:1 ratio with $62 \mathrm{mM}$ Tris $\mathrm{HCl}$ buffer (pH 6.8) containing $20 \%$ glycerol and $0.02 \%$ bromophenol blue. The gel was incubated at $37^{\circ} \mathrm{C}$ in $0.10 \mathrm{M}$ sodium acetate buffer at $\mathrm{pH} 6.5$ for $1 \mathrm{~h}$ and then stained with $0.1 \%$ Congo red.

Determination of protein concentration. The protein concentration was determined using a commercial BioRad kit based on the method proposed by Bradford ${ }^{59}$ using serum albumin as a protein standard.

Determination of xylanase activity. Xylanase activity was determined by adding $20 \mu \mathrm{L}$ of the enzyme at $0.1 \mathrm{mg} /$ $\mathrm{mL}$ to $0.10 \mathrm{M}$ sodium acetate buffer ( $\mathrm{pH}$ 6.5) containing $0.2 \%(\mathrm{w} / \mathrm{v})$ xylan from beechwood (Meganzyme) for $15 \mathrm{~min}$ at $37^{\circ} \mathrm{C}$. Reducing sugars were quantified using the $1-3$-dinitrosalicylic acid (DNS) method ${ }^{60}$, and reading was performed on a spectrophotometer at $540 \mathrm{~nm}$. One unit of enzymatic activity was defined as $1 \mu$ mol of reducing sugar per minute per $\mathrm{mg}$ of protein under the previously established standard test conditions. The tests were carried out in triplicate, and each reaction included a control without the enzyme to measure the spontaneous hydrolysis of the substrate.

Effect of temperature and $\mathrm{pH}$. The optimum $\mathrm{pH}$ for xylanase activity was determined using $0.1 \mathrm{M}$ sodium acetate (pH 3.0-6.5), 0.1 M Tris $\mathrm{HCl}(\mathrm{pH} 6.5-7.5)$ and 0.1 M AMPOL (pH 8.5-10). The optimum temperature was determined by placing the enzyme in $0.1 \mathrm{M}$ sodium acetate buffer at different temperatures $\left(4-95^{\circ} \mathrm{C}\right)$ for $15 \mathrm{~min}$. The parameters $\mathrm{km}$ and Vmax were determined using xylan from beechwood at concentrations of 0.025 to $5 \mathrm{mg} / \mathrm{mL}$ in $0.1 \mathrm{M}$ sodium acetate buffer ( $\mathrm{pH} 6.5$ ).

Effect of metal ions. The influence of the ions $\mathrm{Co}^{+2}, \mathrm{Cu}^{+2}, \mathrm{Hg}^{+2}, \mathrm{Mg}^{+2}, \mathrm{Mn}^{+2}$, and $\mathrm{Zn}^{+2}$ on the activity of xylanase was evaluated at concentrations of $1,2,3,4$ and $5 \mathrm{mM}$ in the reaction medium. The relative activity was calculated from the control of each test, which did not include the addition of ions (100\%).

Effect of sodium chloride. The effect of $\mathrm{NaCl}$ on xylanase activity was evaluated by adding $\mathrm{NaCl}$ at concentrations of 0.1 to $2 \mathrm{M}$ to the reaction medium and exposing the enzyme to $\mathrm{NaCl}$ at concentrations of 0.1 to $2.5 \mathrm{M}$ for 2,4 and $8 \mathrm{~h}$. Relative activity was calculated by adding to each assay a control that did not include the addition of $\mathrm{NaCl}(100 \%)$.

Effect of temperature. The effect of temperature on xylanase activity was determined by preincubation of XylR in the absence of the substrate at $45,50,55$ and $60^{\circ} \mathrm{C}$ for $15,30,45$ and $60 \mathrm{~min}$. After incubation, the activity was determined at $37^{\circ} \mathrm{C}$ and the residual percentage was estimated.

Determination of esterase activity. The esterase activity was determined discontinuously in a spectrophotometer at $405 \mathrm{~nm}$. The reaction was initiated by adding $20 \mu \mathrm{L}$ of the enzyme at $0.1 \mathrm{mg} / \mathrm{mL}$ to $0.1 \mathrm{M}$ sodium acetate buffer at pH 6.5 and $1 \mathrm{mM}$ p-nitrophenyl acetate for $15 \mathrm{~min}$ at $37^{\circ} \mathrm{C}$. Substrate affinity was determined using the following substrates $(1 \mathrm{mM}$, Sigma-Aldrich): $p$-nitrofenyl acetate, $p$-nitrofenyl butyrate, $p$-nitrofenyl valerate, $p$-nitrofenyl octanoate, $p$-nitrofenyl dodecanoate, $p$-nitrofenyl myristate, and $p$-nitrofenyl palmitate. One unit of enzymatic activity was defined as $1 \mu \mathrm{mol} p$-nitrophenol released per minute per $\mathrm{mg}$ of protein under previously established standard assay conditions. The tests were performed in triplicate, and each reaction included a control without the enzyme to measure the spontaneous hydrolysis of the substrate.

Determination of kinetic parameters. The catalytic parameters $\mathrm{K}_{\mathrm{m}}$ (Michaelis-Menten constant), $\mathrm{V}_{\mathrm{ma}} \mathrm{x}$ (maximum reaction speed), kcat (catalytic constant) and kcat. $\mathrm{K}_{\mathrm{m}}{ }^{-1}$ (catalytic efficiency) was determined for endo$\beta$-1,4-xylanase activity with xylan from beechwood as the substrate, and the concentration varied from 0.025 to $2.5 \mathrm{mg} / \mathrm{mL}$. For esterase activity, $p$-nitrofenyl acetate was used as the substrate, and the concentration varied from 0.75 to $5 \mathrm{mM}$. The data were tested using the $\mathrm{F}$ test $(\mathrm{p}<0.05)$ to determine the best kinetic model: $\mathrm{H}_{0}=$ Michaelis-Menten and $\mathrm{H}_{1}=$ sigmoidal. The normality of the residues was verified by the Shapiro-Wilk W test. The hypothesis test and nonlinear regression of the data by the Michaelis-Menten equation were performed using GraphPad Prism Software, version 5.00 for Windows (GraphPad Software, San Diego, California, USA).

Received: 4 June 2020; Accepted: 26 April 2021

Published online: 17 May 2021 


\section{References}

1. Sharma, H. K., Xu, C. \& Qin, W. Biological pretreatment of lignocellulosic biomass for biofuels and bioproducts: an overview. Waste Biomass Valoriz. 10, 235-251 (2019).

2. Sun, S., Sun, S., Cao, X. \& Sun, R. The role of pretreatment in improving the enzymatic hydrolysis of lignocellulosic materials. Bioresour. Technol. 199, 49-58 (2016).

3. Beg, Q. K., Kapoor, M., Mahajan, L. \& Hoondal, G. S. Microbial xylanases and their industrial applications: a review. Appl. Microbiol. Biotechnol. 56, 326-338 (2001).

4. Collins, T., Gerday, C. \& Feller, G. Xylanases, xylanase families and extremophilic xylanases. FEMS Microbiol. Rev. 29, 3-23 (2005).

5. Lombard, V., Golaconda Ramulu, H., Drula, E., Coutinho, P. M. \& Henrissat, B. The carbohydrate-active enzymes database (CAZy) in 2013. Nucleic Acids Res. 42, 490-495 (2014).

6. Basu, M., Kumar, V. \& Shukla, P. Recombinant approaches for microbial xylanases: recent advances and perspectives. Curr. Protein Pept. Sci. https://doi.org/10.2174/1389203718666161122110200 (2017).

7. Kumar, A., Gautam, A. \& Dutt, D. Biotechnological transformation of lignocellulosic biomass in to industrial products: an overview. Adv. Biosci. Biotechnol. 07, 149-168 (2016).

8. de Freitas, C., Carmona, E. \& Brienzo, M. Xylooligosaccharides production process from lignocellulosic biomass and bioactive effects. Bioact. Carbohydr. Diet. Fibre 18, 100184 (2019).

9. Venkateswar Rao, L., Goli, J. K., Gentela, J. \& Koti, S. Bioconversion of lignocellulosic biomass to xylitol: an overview. Bioresour. Technol. 213, 299-310 (2016).

10. Madhavan, A., Sindhu, R., Parameswaran, B., Sukumaran, R. K. \& Pandey, A. Metagenome analysis: a powerful tool for enzyme bioprospecting. Appl. Biochem. Biotechnol. 183, 636-651 (2017).

11. Ogunade, I. M., Lay, J., Andries, K., McManus, C. J. \& Bebe, F. Effects of live yeast on differential genetic and functional attributes of rumen microbiota in beef cattle. J. Anim. Sci. Biotechnol. 10, 1-7 (2019).

12. Deusch, S. et al. A structural and functional elucidation of the rumen microbiome influenced by various diets and microenvironments. Front. Microbiol. 8, 1-21 (2017).

13. Gruninger, R. J., Cote, C., McAllister, T. A. \& Abbott, D. W. Contributions of a unique $\beta$-clamp to substrate recognition illuminates the molecular basis of exolysis in ferulic acid esterases. Biochem. J. 473, 839-849 (2016).

14. Gasteiger, E. et al. Protein Identification and Analysis Tools on the ExPASy Server. in The Proteomics Protocols Handbook 571-607 (Humana Press, 2005). https://doi.org/10.1385/1-59259-890-0:571.

15. Altschul, S. F., Gish, W., Miller, W., Myers, E. W. \& Lipman, D. J. Basic local alignment search tool. J. Mol. Biol. 215, 403-410 (1990).

16. Sievers, F. et al. Fast, scalable generation of high-quality protein multiple sequence alignments using Clustal Omega. Mol. Syst. Biol. https://doi.org/10.1038/msb.2011.75 (2011).

17. Robert, X. \& Gouet, P. Deciphering key features in protein structures with the new ENDscript server. Nucleic Acids Res. 42, W320-W324 (2014)

18. Basit, A., Liu, J., Rahim, K., Jiang, W. \& Lou, H. Thermophilic xylanases: from bench to bottle. Crit. Rev. Biotechnol. 38, 989-1002 (2018).

19. Lin, L. et al. Ruminal microbiome-host crosstalk stimulates the development of the ruminal epithelium in a lamb model. Microbiome 7, 1-16 (2019).

20. Gharechahi, J. \& Salekdeh, G. H. A metagenomic analysis of the camel rumen's microbiome identifies the major microbes responsible for lignocellulose degradation and fermentation. Biotechnol. Biofuels 11, 1-19 (2018).

21. Lazuka, A., Auer, L., O’Donohue, M. \& Hernandez-Raquet, G. Anaerobic lignocellulolytic microbial consortium derived from termite gut: enrichment, lignocellulose degradation and community dynamics. Biotechnol. Biofuels 11, 1-14 (2018).

22. Kishi, L. T., de Jesus, R. B., Pavani, C. D., Lemos, E. G. M. \& de Souza, J. A. M. Metagenomic assembly and draft genome sequence of an uncharacterized prevotella sp. from Nelore Rumen. J. Genome Announc. https://doi.org/10.1128/genomeA.00723-15 (2015).

23. Mirande, C., Mosoni, P., Béra-Maillet, C., Bernalier-Donadille, A. \& Forano, E. Characterization of Xyn 10A, a highly active xylanase from the human gut bacterium Bacteroides xylanisolvens XB1A. Appl. Microbiol. Biotechnol. 87, 2097-2105 (2010).

24. Liao, H. et al. Functional diversity and properties of multiple xylanases from Penicillium oxalicum GZ-2. Sci. Rep. 5, 12631 (2015).

25. Nakamura, A. M., Nascimento, A. S. \& Polikarpov, I. Structural diversity of carbohydrate esterases. Biotechnol. Res. Innov. 1, 35-51 (2017).

26. Petersen, T. N., Brunak, S., von Heijne, G. \& Nielsen, H. SignalP 4.0: discriminating signal peptides from transmembrane regions. Nat. Methods 8, 785-786 (2011).

27. Shi, H. et al. Cloning, over-expression and characterization of a thermo-tolerant xylanase from Thermotoga thermarum. Biotechnol. Lett. 36, 587-593 (2014).

28. McPhillips, K. et al. Purification and Characterisation of a $\beta-1,4$-Xylanase from Remersonia thermophila CBS 540.69 and Its Application in Bread Making. Appl. Biochem. Biotechnol. 172, 1747-1762 (2014).

29. Bai, W., Xue, Y., Zhou, C. \& Ma, Y. Cloning, expression and characterization of a novel salt-tolerant xylanase from Bacillus sp. SN5. Biotechnol. Lett. 34, 2093-2099 (2012).

30. Arpigny, J. L. \& Jaeger, K.-E. Bacterial lipolytic enzymes: classification and properties. Biochem. J. 343, 177 (1999).

31. Liu, Y. et al. Biochemical characterization of a first fungal esterase from rhizomucor miehei showing high efficiency of ester synthesis. PLoS ONE 8, e77856 (2013).

32. Rao, L., Xue, Y., Zheng, Y., Lu, J. R. \& Ma, Y. A novel alkaliphilic bacillus esterase belongs to the 13th bacterial lipolytic enzyme family. PLoS ONE 8, e60645 (2013).

33. Dodd, D. et al. Biochemical analysis of a $\beta$-d-xylosidase and a bifunctional xylanase-ferulic acid esterase from a xylanolytic gene cluster in prevotella ruminicola 23. J. Bacteriol. 191, 3328-3338 (2009).

34. Pai, C.-K. et al. Molecular cloning and characterization of a bifunctional xylanolytic enzyme from Neocallimastix patriciarum. Appl. Microbiol. Biotechnol. 85, 1451-1462 (2010).

35. Wefers, D. et al. Biochemical and structural analyses of two cryptic esterases in bacteroides intestinalis and their synergistic activities with cognate xylanases. J. Mol. Biol. 429, 2509-2527 (2017).

36. Biely, P., MacKenzie, C. R., Puls, J. \& Schneider, H. Cooperativity of esterases and xylanases in the enzymatic degradation of acetyl xylan. Nat. Biotechnol. 4, 731-733 (1986).

37. Ratanachomsri, U. et al. Thermostable xylanase from Marasmius sp.: purification and characterization. BMB Rep. 39, 105-111 (2006).

38. Huang, J., Wang, G. \& Xiao, L. Cloning, sequencing and expression of the xylanase gene from a Bacillus subtilis strain B10 in Escherichia coli. Bioresour. Technol. 97, 802-808 (2006).

39. Rahmani, N. et al. GH-10 and GH-11 Endo-1,4- $\beta$-xylanase enzymes from Kitasatospora sp. produce xylose and xylooligosaccharides from sugarcane bagasse with no xylose inhibition. Bioresour. Technol. 272, 315-325 (2019).

40. Khandeparker, R., Verma, P. \& Deobagkar, D. A novel halotolerant xylanase from marine isolate Bacillus subtilis cho40: gene cloning and sequencing. N. Biotechnol. 28, 814-821 (2011).

41. AL-Darkazali, H., Meevootisom, V., Isarangkul, D. \& Wiyakrutta, S. Gene expression and molecular characterization of a xylanase from chicken cecum metagenome. Int. J. Microbiol. 2017, 1-12 (2017). 
42. Park, D.-J. An $\beta$-1,4-xylanase with exo-enzyme activity produced by paenibacillus xylanilyticus KJ-03 and its cloning and characterization. J. Microbiol. Biotechnol. 23, 397-404 (2013).

43. Wang, G., Huang, X., Ng, T. B., Lin, J. \& Ye, X. Y. High phylogenetic diversity of glycosyl hydrolase family 10 and 11 xylanases in the sediment of lake dabusu in China. PLoS ONE 9, el12798 (2014).

44. Vassilev, S. V., Vassileva, C. G. \& Vassilev, V. S. Advantages and disadvantages of composition and properties of biomass in comparison with coal: an overview. Fuel 158, 330-350 (2015).

45. Gupta, S., Bhushan, B. \& Hoondal, G. S. Isolation, purification and characterization of xylanasefrom Staphylococcus sp. SG-13 and its application in biobleaching of kraft pulp. J. Appl. Microbiol. 88, 325-334 (2000).

46. Ghadikolaei, K. K., Sangachini, E. D., Vahdatirad, V., Noghabi, K. A. \& Zahiri, H. S. An extreme halophilic xylanase from camel rumen metagenome with elevated catalytic activity in high salt concentrations. AMB Express 9,86 (2019).

47. Li, Z. et al. The critical roles of exposed surface residues for the thermostability and halotolerance of a novel GH11 xylanase from the metagenomic library of a saline-alkaline soil. Int. J. Biol. Macromol. 133, 316-323 (2019).

48. Raza, A., Bashir, S. \& Tabassum, R. An update on carbohydrases: growth performance and intestinal health of poultry. Heliyon 5, e01437 (2019).

49. Jiang, Z., Yi, J., Li, J., He, T. \& Hu, C. Promoting effect of sodium chloride on the solubilization and depolymerization of cellulose from raw biomass materials in water. Chemsuschem 8, 1901-1907 (2015).

50. Aragon, C. C. et al. Continuous production of xylooligosaccharides in a packed bed reactor with immobilized-stabilized biocatalysts of xylanase from Aspergillus versicolor. J. Mol. Catal. B Enzym. 98, 8-14 (2013).

51. Powell, S. et al. eggNOG v4.0: nested orthology inference across 3686 organisms. Nucleic Acids Res. 42, D231-D239 (2014).

52. Thompson, J. D., Higgins, D. G. \& Gibson, T. J. CLUSTAL W: Improving the sensitivity of progressive multiple sequence alignment through sequence weighting, position-specific gap penalties and weight matrix choice. Nucleic Acids Res. 22, 4673-4680 (1994).

53. Finn, R. D. et al. Pfam: the protein families database. Nucleic Acids Res. 42, D222-D230 (2014).

54. El-Gebali, S. et al. The Pfam protein families database in 2019. Nucleic Acids Res. 47, D427-D432 (2019).

55. Pavani, C. D. Potencial biotecnológico do metageoma de rúmen bovino da raça Nelore (Bos tauros indicus), visando à desconstrução da biomassa vegetal. (Unesp, Jaboticabal, 2017).

56. Yamada, Y. et al. Molecular analysis of Japanese patients with Rett syndrome: Identification of five novel mutations and genotypephenotype correlation Communicated by Mark H Paalman Online Citation: Human Mutation, Mutation in Brief \#443 (2001) Online http://journals.wil. Hum. Mutat. 18, 253 (2001).

57. Hall, T. A. BIOEDIT: a user-friendly biological sequence alignment editor and analysis program for Windows 95/98/ NT. Nucleic Acids Symp. Ser. 41, 95-98 (1999).

58. Laemmli, U. K. Cleavage of structural proteins during the assembly of the head of bacteriophage T4. Nature 227, 680-685 (1970).

59. Bradford, M. M. A rapid and sensitive method for the quantitation of microgram quantities of protein utilizing the principle of protein-dye binding. Anal. Biochem. https://doi.org/10.1016/0003-2697(76)90527-3 (1976).

60. Miller, G. L. Use of dinitrosalicylic acid reagent for determination of reducing sugar. Anal. Chem. 31, 426-428 (1959).

\section{Acknowledgements}

We thank the financial support of CAPES (Coordination of Improvement of Higher Level Personnel), the graduate program in Agricultural Microbiology (Universidade Estadual Paulista, UNESP-FCAV), the Fundação de Amparo à Pesquisa do Estado de São Paulo FAPESP for research fellowships and Grant 2018/12885-0) and Coordenação de Aperfeiçoamento de Pessoal de Nível Superior (CAPES, Finance Code 001).

\section{Author contributions}

G.C.P., E.G.M.L. and J.M.P. Jr contributed to the design and implementation of the research. G.C.P. and N.S.M.L. contributed to the analysis of the results. All authors and the writing and reviewed of the manuscript.

\section{Competing interests}

The authors declare no competing interests.

\section{Additional information}

Supplementary Information The online version contains supplementary material available at https://doi.org/ 10.1038/s41598-021-89916-8.

Correspondence and requests for materials should be addressed to J.M.P.J.

Reprints and permissions information is available at www.nature.com/reprints.

Publisher's note Springer Nature remains neutral with regard to jurisdictional claims in published maps and institutional affiliations.

Open Access This article is licensed under a Creative Commons Attribution 4.0 International License, which permits use, sharing, adaptation, distribution and reproduction in any medium or format, as long as you give appropriate credit to the original author(s) and the source, provide a link to the Creative Commons licence, and indicate if changes were made. The images or other third party material in this article are included in the article's Creative Commons licence, unless indicated otherwise in a credit line to the material. If material is not included in the article's Creative Commons licence and your intended use is not permitted by statutory regulation or exceeds the permitted use, you will need to obtain permission directly from the copyright holder. To view a copy of this licence, visit http://creativecommons.org/licenses/by/4.0/.

(C) The Author(s) 2021 